\section{TOWARDS ECOLOGICAL AUTARKY}

Michel van Dartel and Anne Nigten, Hanze University of Applied Sciences, Groningen, The Netherlands. E-mail: michel@v2.nl,

a.m.m.nigten@pl.hanze.nl

\begin{abstract}
While the notion of autarky is often contested in terms of feasibility and desirability, art and design projects that deal with autarky seem to moreover suggest positive socio-cultural and ecological effects of autarkic living. A social network model of autarky is introduced to unify these seemingly opposing views.
\end{abstract}

Increasing self-sufficiency with respect to ecological resources such as food, energy and water is regarded an important factor in the transition towards a more sustainable future $[1,2,3]$. Greater self-sufficiency arguably leads to independence from the infrastructures responsible for climate change (e.g., mass food processing, centralized energy production systems and transport infrastructures) while simultaneously giving rise to greater adaptability to changes in climate [4]. Such autonomy with respect to the external provision of ecological resources is commonly referred to as 'ecological autarky'. Food autarky, for instance, is the degree to which a community can feed itself [5] and electricity autarky refers to independence from centralized energy providers [6]. Although ecological autarky is often contested on grounds of feasibility [7], desirability [8] and even sustainability [9], ecological autarky is a recurring topic in discussions around scenarios for a sustainable future $[10,11]$. What do art and design perspectives on autarky contribute to the discussion around scenarios for a sustainable future? In the below, three notable media artworks are analyzed in the light of this question. The analysis was conducted as part of the Energize people project [12] in the context of the forthcoming Energize festival [13].

In 1994, artist Marco Peljhan (SI) initiated a quintessential example of an artistic project exploring ecological autarky titled MAKROLAB [14]. Central to the project is a mobile unit that harvests its own wind and sun energy, recycles most of its waste, and offers isolated research and living conditions to four people for up to 120 days. In these isolated conditions, artists and researchers have explored tools and tactics in relation to telecommunications, weather systems and migration. MAKROLAB's greatest achievement has however been argued its contribution to engaging communities around the politics of globalization [15]. Besides the experimentation conducted in and around

$M A K R O L A B$, the mobile unit itself also has a political dimension: for instance, it proposes that ecological autarky is possible without a return to primitivism (cf. [16]) and furthermore shows that technology may offer a means to realize a more sustainable relation to nature as well as foster social exchange, rather than alienating us from nature and each other (cf. [17]).

The intervention project World in a Shell (WiaS), initiated by artist Hans Kalliwoda (NL), recently revived the discussion around ecological autarkic tools and tactics in art and design [18]. Although also centering around a selfsustainable living and working unit, in contrast to MAKROLAB, WiaS does not aim for interdisciplinary exchange between international experts, but instead proposes to deploy the unit to engage indigenous people at rural sites in discussions about their relation to nature. The knowledge harvested from these discussions is documented and will travel with WiaS to the next locations, where the documentation from previous discussions serves as input to similar discussions at the new site. By doing so, the project aims for cultural crosspollination between geographically disconnected rural communities. Just as MAKROLAB, WiaS aims to facilitate knowledge exchange on sustainable living, rather than imposing a solution.

Nevertheless, both projects deliberately embody an ecological autarkic scenario to facilitate such knowledge exchange. Neither MAKROLAB nor WiaS are fully ecologically autarkic however, since both strongly depend on transport infrastructures. WiaS is for instance even specifically built to fit a conventional sea container to relocate by means of standard logistic infrastructures.

Artist collective N55 (DK) realized an ecological autarkic scenario that overcomes this reliance on transport infrastructures by creating a self-sustainable unit that moves on six 'legs', aptly titled Walking House [19]. By for instance using solar cells on the roof of the unit to harvest energy and by collecting and filtering rainwater for consumption and agriculture, the unit provides comfortable living independent from existing energy and water infrastructures. Furthermore, Walking House features a composting toilet system to dispose of sewage and has a small greenhouse unit and small wood burning stove to provide food and $\mathrm{CO}^{2}$-neutral heating. While similar modules for water, energy and food autarky have been developed in the context of MAKROLAB and WiAS, the Walking House is unique in that it is also autonomous with respect to transport infrastructure; the unit does not even require roads, as the structure can basically move on any flat surface. Walking House thereby seems to have crossed the final frontier in ecological autarky, allowing full self-sufficiency with respect to shelter, waste, food, energy, water and transportation. According to N55, the true strength of Walking House is that it relieves humans from owning land and disturbing the environment, resulting in true freedom and peaceful living [20].

It seems that all three art projects discussed above, besides speculating on ecological gains, also suggest that autarkic living may bring along positive socio-cultural effects, such as political engagement of communities, knowledge exchange between communities, individual freedom and overall peaceful living. These socio-cultural advantages of autarky are the direct result of independence from ecological infrastructures allowing nomadic ways of living. A societal shift to more nomadic ways of living in mobile or portable shelters (i.e., 'the age of new nomadism' [21]) would of course bring along enormous economical, political and sociocultural implications. While scientists and policy-makers generally discuss the political and economical consequences of ecological au- 
tarky at a nation-state level (e.g., [22, 23]), artists and designers developing autarkic scenarios seem to moreover contribute knowledge regarding the socio-cultural implications of autarky at the individual and community level. Furthermore, art and design put the notion of ecological autarky into practice through objects, installations, performances and interventions that may serve as proof of concept or intend to generate discussion. In the absence of such concrete models, socio-cultural effects are easily ignored when evaluating autarkic scenarios from a mere political or economic angle. Or, in the words of N55, there is "little value in theorizing without producing a physical result" [24]. The speculative models produced by artists and designers therefore seem to play a crucial role in evaluating new balances between ecological autarky and dependency on external provision of ecological resources through infrastructures.

Although ecological autarky may not be desirable or more sustainable at the nation-state level, the three examples above show that it may be a desirable, and arguably also sustainable, alternative at an individual or community level. If one individual in a community for instance grows potatoes, while another grows tomatoes and both trade half their crops, this may be more efficient use of the ecological resources present in a community than when each would grow their own [25]. At a nation-state level this may however result in dependencies between nation-states that could lead to unsustainable behavior such as longdistance transport of food and vulnerability to food insecurity [26]. It therefore seems that a sustainable future depends on a balance between ecological autarky at certain levels of social organization, while dependency on external provisions may be preferred at other levels.

Another way to look at this is by adopting a social network approach to autarky (cf. [27]). Looking at society as a global network of individuals, autarky could occur at any intermediate level between an individual and the network as a whole. Individuals or communities within the network could even (physically or virtually) form clusters to be autar- kic together. From this perspective, the question is not whether to live autarkic with respect to ecological resources or to be dependent on infrastructures, but what the best level is to organize ecological resources at. While for some ecological resources small communities could best be autarkic, for others it may be better to be autarkic at a regional, national or global level. (Or all three, as argued for energy in [28].) Autarkic scenarios should therefore never be regarded as ultimate solutions for all ecological resources at all social levels.

In a time where the threat of climate change calls for a global humanistic and ecological transition, it is important that not only the economic and political consequences of scenarios for a more sustainable future are theorized at the nation-state level. Their implications should also be explored on the level of individuals and communities on the basis of concrete models. As illustrated above, artists and designers have valuable tools to offer in investigating socio-cultural implications of possible future scenarios, such as ecological autarky. To be effective however, such art and design projects should not merely be exhibited, but also be critically evaluated, compared and related to work in other domains. Only that way the critical discourse will emerge that is necessary for these art and design perspectives to be heard within the realm of policy-making. This article is a modest attempt at doing so.

\section{References and Notes}

1. J. van Andel and J. Aronson (Eds.), Restoration ecology. (Oxford, U.K.: Blackwell, 2006).

2. A. Hoekstra and A. Chapagain, "The Water Footprints of Nations: Water Use by People as a Function of their Consumption Pattern," Water Resource Management 21 (2007) pp. 35-48.

3. Food and Agriculture Organisation of the UN, $<$ http://www.fao.org/docrep/014/i2316e/i2316e 00 .pdf $>$, accessed 5 May 2012.

4. C. Field, V. Barros, T. Stocker, D. Qin, D. Dokken, K. Ebi, M. Mastrandrea, K. Mach, G.K. Plattner, S. Allen, M. Tignor, and P. Midgley (Eds.), Managing the Risks of Extreme Events and Disasters to Advance Climate Change Adaptation. (Cambridge, U.K.: Cambridge Univ. Press, 2012).

5. M. Hobbes, Figuring Rural Development: Concepts and Cases of Land Use, Sustainability, and integrative indicators (Amsterdam, N.L.: Amsterdam Univ. Press, 2010).

6. J. Schmidt, M. Schönhart, M. Biberacher, T. Guggenberger, S. Hausl, G. Kalt, S. Leduc, I. Schardinger and E. Schmid, "Regional energy autarky: Potentials, costs and consequences for an Austrian region," Energy Policy 47 (August 2012) pp. 211-221.

7. Gal Luft, "Energy self-sufficiency: A realistic goal or a pipe dream?",

$<$ http://ourworld.unu.edu/en/energy-selfsufficiency-a-realistic-goal-or-a-pipe-dream>, accessed 19 May 2013.

8. Ludwig von Mises, Money, Method and the Market Process, R. Ebeling, ed. (Norwell, Mass.: Kluwer Academic Press, 1990).

9. European Commission's Director-General for Regional and Urban Policy, "Connecting Smart and Sustainable Growth through Smart Specialisation,"

$<$ http://ec.europa.eu/regional_policy/sources/do cgener/presenta/green_growth/greengrowth.pdf $>$, accessed 1 July 2013.

10. M. Hodson and S. Marvin, "Urban Ecological Security' A New Urban Paradigm?" International Journal of Urban and Regional Research 33 (March 2009) pp. 193-215.

11. Hobbes [5].

12. Energize People is a research project by the PSI research group, Centre of Applied research Art $\&$ Society, Hanze University of Applied Sciences, funded by the Ministry of Economic Affairs of the Netherlands in 2013.

13. The Energize festival is organized by the research group PSI of the Hanze University of Applied Sciences in Groningen.

14. Marko Peljhan, Makrolab (London, U.K.: Arts Catalyst, 2003).

15. Johannes Birringer, "Makrolab: A Heterotopia", Journal of Performance and Art, 60. (September 1998) pp. 66 - 75.

16. John Zerzan, Future Primitive and other essays (New York, U.S.: Autonomedia, 1994).

17. Adam Curtis, All Watched Over by Machines of Loving Grace, 2 (2011), TV series.

18. Hans Kalliwoda, World in a Shell. (Amsterdam, N.L.: Blindpainters, 2009).

19. N55, "Manual for Walking House", $<$ http://www.n55.dk/MANUALS/WALKING HOUSE/walkinghouse.html>, accessed 8 April 2013.

20. Peter Kelly, "The Challenging Lifestyle of N55's Ion Sørvin,"

http://www.blueprintmagazine.co.uk/index.php /architecture/the-challenging-lifestyle-of-n55sion-sørvin, accessed 19 May 2013.

21. Jennifer Siegal (ed.), MOBILE: The Art of Portable Architecture (New York, U.S.: Princeton Architectural Press, 2003).

22. P. Taylor and C. Flint Political geography: world-economy, nation-state and locality. (New Jersey, U.S.: Prentice Hall, 2000).

23. M. Common and S. Stagl, Ecological Economics: An Introduction. (Cambridge U.K.: Cambridge University Press, 2005).

24. Kelly [20].

25. Katrien van der Straeten, "What and Who is Self-Sufficient?",

<http://suite101.com/article/what-and-who-isselfsufficient-a21367>, accessed 1 July 2013.

26. Food and Agriculture Organization of the UN, <http://www.fao.org/forestry/15538079b31d45081fe9c3dbc6ff34de4807e4.pdf>, accessed 11 May 2012.

27. Bruno Latour, Reassembling the social. (Oxford, U.K.: Oxford University Press, 2005).

28. Jan Rotmans, In het oog van de orkaan. (Boxtel, N.L.: Æneas publishers, 2012). 